\title{
A new method for the assessment of reduction tension during open reduction in patients with developmental dysplasia of the hip
}

\author{
Gelişimsel kalça displazili hastalarda açık redüksiyon sırasında redüksiyon sıkılığının \\ değerlendirilmesi için yeni bir yöntem
}

\author{
Oktay Adanır, MD (D), Serdar Yüksel, MD (D), Ozan Beytemur, MD (D) \\ Department of Orthopedics and Traumatology, Bağcılar Training and Research Hospital, Istanbul, Turkey
}

\begin{abstract}
Objectives: This study aims to describe our standardized method for evaluating the tension of reduction around the hip joint during open reduction in patients with developmental dysplasia of the hip (DDH).
\end{abstract}

Patients and methods: We retrospectively evaluated 67 pediatric patients ( 8 males, 59 females; mean age $21.9 \pm 11.1$ months; range, 9 to 67 months) who were performed open reduction or open reduction with concomitant pelvic and/or femoral osteotomy for DDH at our clinic between January 2009 and March 2014. The amount of distraction between femoral head and acetabulum was measured to evaluate the tension of reduction during surgery. Factors associated with avascular necrosis (AVN) such as age at reduction, presence of concomitant pelvic and/or femoral shortening osteotomy, and severity of dislocation were determined.

Results: Statistically significant association was found between the presence of femoral osteotomy, severity of dislocation, and amount of distraction and AVN. The incidence of AVN was $38.8 \%$ (10 grade I, 12 grade II, 3 grade III, and one grade IV $\mathrm{AVN}$ ). Cut-off value for the amount of distraction to prevent the development of AVN was calculated as $4 \mathrm{~mm}$.

Conclusion: According to our study findings, we advise using our technique for the evaluation of the tension of reduction around the hip joint and performing tension free reduction in the treatment of $\mathrm{DDH}$ to minimize the risk of AVN development.

Keywords: Avascular necrosis of the femoral head, developmental dysplasia of the hip, reduction, risk assessment.
$\ddot{O Z Z}$

Amaç: Bu çalışmada, gelişimsel kalça displazisi (GKD) olan hastalarda açı redüksiyon sırasında kalça eklemi çevresinde redüksiyonun sıkılığını değerlendirmek için standardize edilmiş yöntemimiz açıklandı.

Hastalar ve yöntemler: Ocak 2009 - Mart 2014 tarihleri arasında kliniğimizde GKD nedeniyle açık redüksiyon veya açık redüksiyon ile birlikte pelvik veya femoral osteotomi yapılan 67 pediatrik hasta (8 erkek, $59 \mathrm{kız}$;

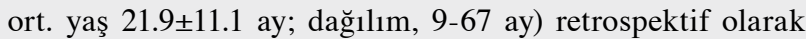
değerlendirildi. Cerrahi sırasında redüksiyon sıkılı̆̆ını değerlendirmek için femur başı ile asetabulum arasındaki distraksiyon miktarı ölçüldü. Redüksiyon sırasındaki yaş, eşlik eden pelvik veya femoral kısaltma osteotomisi varlığ ve dislokasyon şiddeti gibi avasküler nekroz (AVN) ile ilişkili faktörler belirlendi.

Bulgular: Avasküler nekroz ile femoral ostetomi varlığı, dislokasyon şiddeti ve distraksiyon miktarı arasında istatistiksel olarak anlamlı ilişki bulundu. Avasküler nekroz insidansı $\% 38.8$ idi (10 evre I, 12 evre II, 3 evre III ve bir evre IV AVN). Avasküler nekroz gelişimini engellemek için gereken distraksiyon miktarı için eşik değer $4 \mathrm{~mm}$ olarak hesapland.

Sonuç: Çalışma bulgularımıza göre, GKD tedavisinde AVN gelişimi riskini en aza indirmek için kalça eklemi çevresinde redüksiyon sıkılığının değerlendirilmesi amacıyla yöntemimizin kullanılmasını ve sıkı olmayan bir redüksiyon yapılmasını öneriyoruz.

Anahtar sözcükler: Femur başı avasküler nekrozu, gelişimsel kalça displazisi, redüksiyon, risk değerlendirmesi. 
Avascular necrosis (AVN) is one of the main complications associated with the treatment of developmental dysplasia of the hip (DDH). It is a potentially devastating complication that can lead to acetabular dysplasia and joint incongruity and cause premature osteoarthritis. ${ }^{[1,2]}$ The reported incidence of AVN ranges widely from 3 to $60 \%{ }^{[1,3]}$ This wide range in the literature is due to differences in diagnostic criteria used, different methods of selecting patients, and different treatments. ${ }^{[4]}$ However, it is widely accepted that early diagnosis and treatment of DDH are largely successful, with a low risk of AVN..$^{[5,6]}$ Commonly claimed mechanisms in the development of AVN are extrinsic blood vessel compression and excessive pressure on the femoral head, both of which prevent perfusion of the femoral head. Immobilization of the hip in extreme positions such as excessive abduction and internal rotation which in turn cause extrinsic compression of the vessels supplying the femoral head is reported as a major risk factor for AVN development in the literature. ${ }^{[7,8]}$ Preliminary traction and femoral shortening are also methods applied in the literature to decrease pressure on the femoral head to prevent the development of AVN..$^{[9-11]}$

As far as we know, there is no standardized method to evaluate the tension around the hip joint during open reduction of hip joint. We, therefore, developed a pulley and weight system similar to that used during skin or skeletal traction. Instead of manual traction of the leg, we used a sterile rope and pulley system with weights equal to $20 \%$ of the body weight of the child to determine the tension around the hip joint during surgery. Therefore, in this study, we aimed to describe our standardized method for evaluating the tension of reduction around the hip joint during open reduction in patients with DDH.

\section{PATIENTS AND METHODS}

We retrospectively examined pediatric patients who were treated at Bağcılar Training and Research Hospital between January 2009 and March 2014. with open reduction alone or open reduction with concomitant pelvic and/or femoral osteotomy for DDH. Patients with a follow-up period of less than 12 months, teratologic hip dislocation, hip dislocations associated with neuromuscular diseases or septic dislocations, patients with history of failed Pavlik harness usage, or those who had undergone previous closed or open reduction at our or another institution were excluded. One child was also excluded because she had redislocation and underwent a second open reduction three months after primary open reduction. After these exclusions, a total of 67 children (8 males, 59 females; mean age $21.9 \pm 11.1$ months; range, 9 to 67 months) remained who had not been previously treated. Age at reduction, type of surgery, severity of dislocation, and amount of distraction of femoral head from acetabulum during surgery were noted for the 67 patients from their medical records and preoperative radiographs. The study protocol was approved by the Bağclar Training and Research Hospital Ethics Committee. A written informed consent was obtained from parents of patients. The study was conducted in accordance with the principles of the Declaration of Helsinki.

We applied skeletal traction for two weeks before open reduction for all the children younger than 24 months and believe this reduced our AVN rates, hence we continue to use it. All open reductions were performed by two experienced orthopedic surgeons through anterior approach with similar treatment algorithms and techniques. The decision for pelvic and femoral shortening

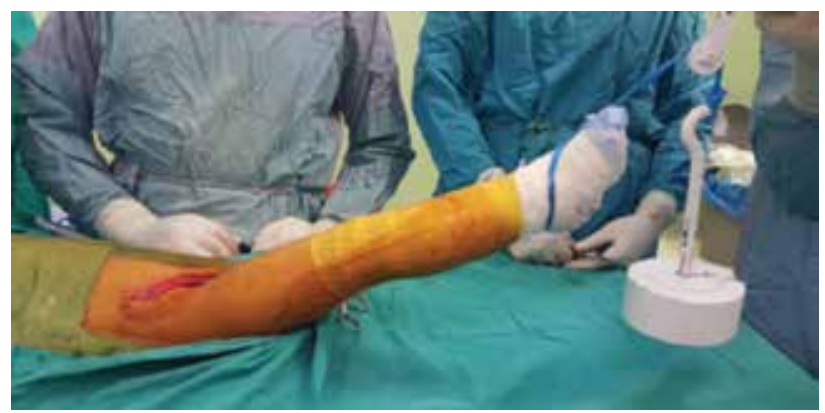

Figure 1. Sterile pulley system and application of traction to extremity.

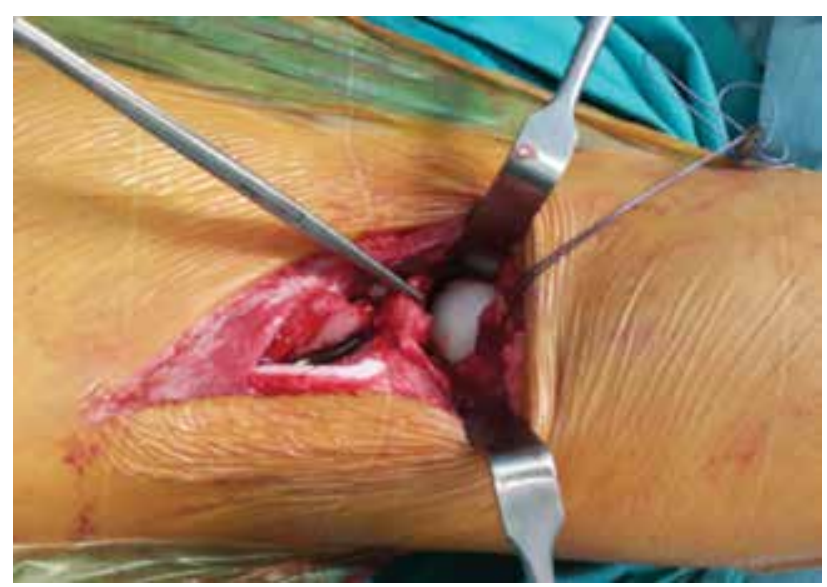

Figure 2. Distraction between femoral head and acetabulum during traction. 


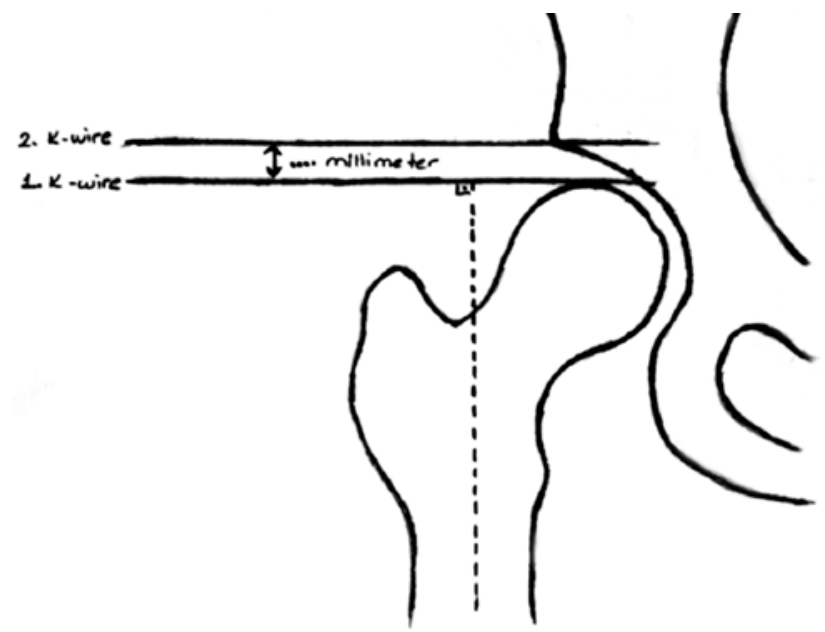

Figure 3. Measurement method of amount of distraction between femoral head and acetabulum.

osteotomy was given according to age of the patient, severity of acetabular dysplasia on preoperative radiographs, and intraoperative findings. Femoral shortening osteotomy was performed through another lateral incision. Before capsular closure, tension around the hip joint was evaluated using a sterile rope and pulley system with weights equal to $20 \%$ of the body weight of the child while hip was in a $30^{\circ}$ flexed position (Figures 1 and 2). The amount of distraction between a $1.2 \mathrm{~mm}$ Kirschner wire (K-wire) placed perpendicular to the femoral diaphysis and tangential to the top femoral head and a second $1.2 \mathrm{~mm}$ K-wire placed tangential to the most lateral point of acetabular roof and parallel to the first K-wire was measured using a sterile ruler and recorded in surgery notes in millimeters. K-wires were just placed over the bones (not inserted into the bones) and checked by fluoroscopy (Figure 3).
After surgery, the hip joints were immobilized in $30^{\circ}-40^{\circ}$ flexion, $30^{\circ}-40^{\circ}$ abduction, and $10^{\circ}$ internal rotation for six weeks in a hip spica cast. After cast removal, patients wore three months full-time and three more months night-time abduction orthosis. All patients were strictly instructed to come for regular follow-up visits.

Severity of the dislocation was graded according to Tönnis classification ${ }^{[12]}$ on preoperative radiographs. Patients' hips were grouped based on the amount of distraction between femoral head and acetabulum. Group A consisted of hips that had 1-3 mm distraction, group $B$ consisted of hips that had 4-6 mm distraction, and group $C$ consisted of hips that had 7-9 $\mathrm{mm}$ distraction. The incidence of AVN of grades I to IV according to Bucholz and Ogden was determined by examining the latest radiographs of the patients..$^{[13]}$

\section{Statistical analysis}

Descriptive statistics of the data are given as mean, standard deviation, median, minimum, maximum, frequency, and percentage values. Distribution of variables was measured with the Kolmogorov-Smirnov test. The Mann-Whitney U test and independent samples t-test were used for analysis of the quantitative data. As for the analyzation of the qualitative data, the chi-square test was used. The degree of effect was researched with univariate and multivariate logistic regression. Analyses were completed using the IBM SPSS version 22.0 program (IBM Corp., Armonk, NY, USA).

\section{RESULTS}

The mean duration of follow-up from operation date to the latest radiographs was $43.1 \pm 17.9$ months (range, 12 to 82 months). Thirty-one right and 36 left hips were evaluated (Table I).

TABLE I

Demographic characteristics of patients

\begin{tabular}{|c|c|c|c|c|c|}
\hline & $\mathrm{n}$ & $\%$ & Mean $\pm S D$ & Median & Min-Max \\
\hline Age (month) & & & $21.9 \pm 11.1$ & 18 & $9-67$ \\
\hline \multicolumn{6}{|l|}{ Gender } \\
\hline Female & 59 & 88.1 & & & \\
\hline Male & 8 & 11.9 & & & \\
\hline Follow-up period (month) & & & $48.1 \pm 10.9$ & 40 & $36-82$ \\
\hline \multicolumn{6}{|l|}{ Side of involvement } \\
\hline Right & 31 & 46.3 & & & \\
\hline Left & 36 & 53.7 & & & \\
\hline
\end{tabular}

SD: Standard deviation; Min: Minimum; Max: Maximum. 
TABLE II

Investigation of variables playing a role in avascular necrosis etiology

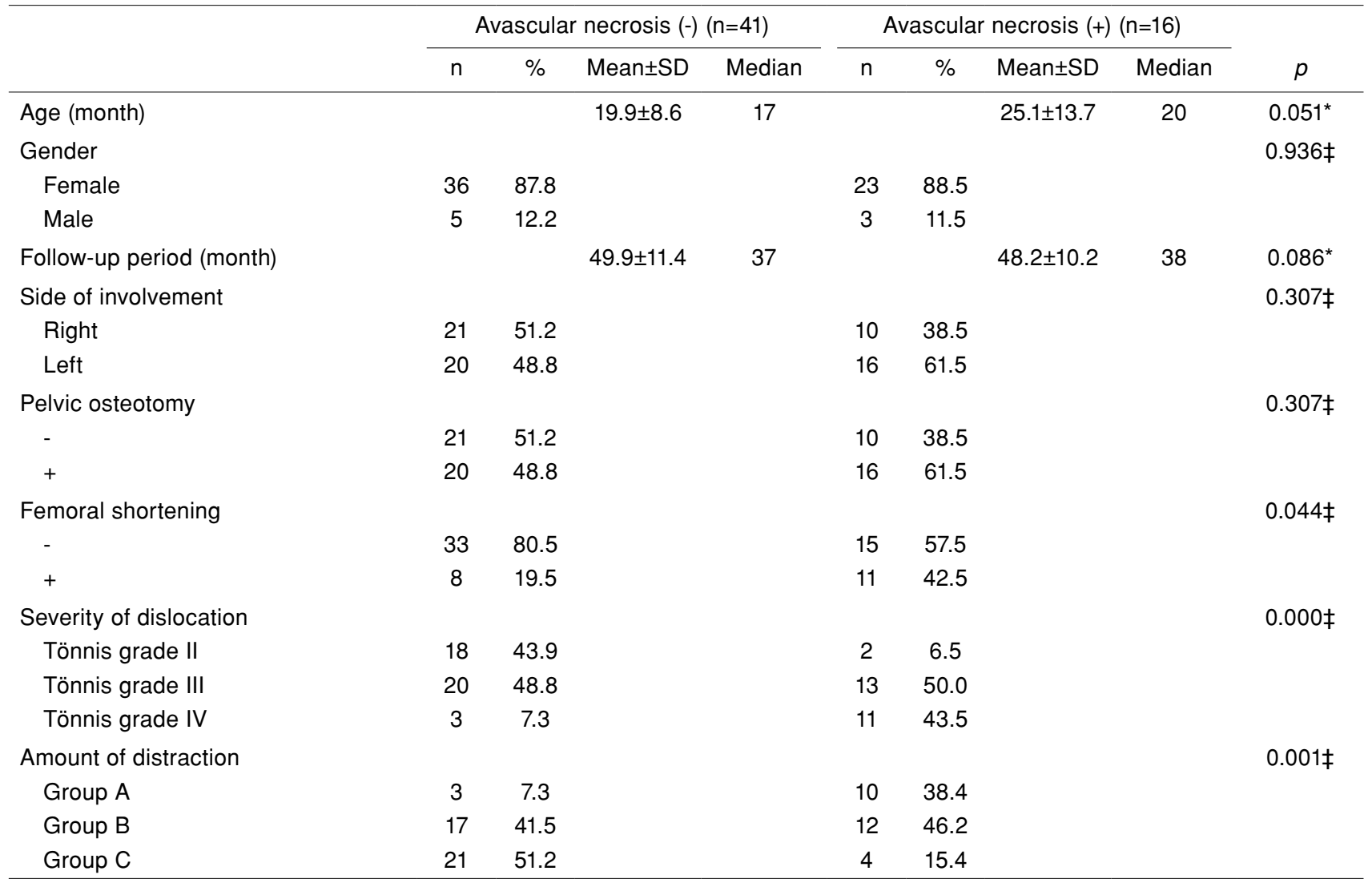

SD: Standard deviation; * Mann-Whitney U test; $¥$ Chi-square test.

There were 20 Tönnis grade II, 33 grade III, and 14 grade IV hips. The incidence of AVN was 38.8\% (10 grade I, 12 grade II, 3 grade III, and one grade IV AVN). If only Bucholz and Ogden grades II and greater are considered, the incidence of AVN was $23.9 \%$. There were 13 hips in group A, 29 hips in group B, and 25 hips in group $C$ according to the distraction amount of the femoral head from the acetabulum. There were 10 hips with AVN in group A (38.5\%), 12 hips with AVN in group B (46.2\%), and four hips with AVN in group C (15.4\%).
There was no association between age at reduction $(p=0.051)$, gender $(p=0.936)$, operation side $(\mathrm{p}=0.307)$, presence of pelvic osteotomy $(\mathrm{p}=0.307)$, and presence of AVN. Statistically significant associations were found between presence of femoral osteotomy $(\mathrm{p}=0.044)$, severity of dislocation $(\mathrm{p}=0.001)$, and amount of distraction $(\mathrm{p}=0.001)$ and the presence of AVN (Table II).

In the univariate model, there were significant effects of femoral shortening, degree of dislocation,

TABLE III

Logistic regression analysis

\begin{tabular}{|c|c|c|c|c|c|c|}
\hline & \multicolumn{3}{|c|}{ Univariate model } & \multicolumn{3}{|c|}{ Multivariate model } \\
\hline & OR & $95 \% \mathrm{Cl}$ & $p$ & OR & $95 \% \mathrm{Cl}$ & $p$ \\
\hline Femoral shortening & 3.02 & $1.01-9.05$ & 0.048 & & & \\
\hline Severity of dislocation & 7.92 & $1.92-32.63$ & 0.004 & 4.77 & $1.77-12.83$ & 0.002 \\
\hline Amount of distraction $(\mathrm{A} / \mathrm{B} / \mathrm{C})$ & 5.74 & $2.19-15.03$ & 0.000 & 4.81 & $1.02-22.66$ & 0.047 \\
\hline
\end{tabular}

OR: Odds ratio; $\mathrm{Cl}$ : Confidence interval; LR: Logistic regression (univariate model/multivariate model -forward- LR). 
TABLE IV

Statistical evaluation of amount of distraction between avascular necrosis (+) and (-) groups

\begin{tabular}{ccccc}
\hline & \multicolumn{3}{c}{ Amount of distraction $(\mathrm{mm})$} & \\
\cline { 2 - 5 } & Mean \pm SD & Median & Min-Max & $0.000^{*}$ \\
\hline Avascular necrosis & & & & \\
- & $6.5 \pm 1.8$ & 7.0 & $3.0-9.0$ & \\
+ & $3.7 \pm 2.1$ & 4.0 & $1.0-8.0$ & \\
\hline
\end{tabular}

SD: Standard deviation; Min: Minimum; Max: Maximum; ${ }^{*}$ Mann-Whitney U test.

and amount of distraction $(\mathrm{p}<0.05)$ in differentiation of the patients positive or negative for AVN. In the multivariate model, there were significant independent $(p<0.05)$ effects of the degree of dislocation and the amount of distraction in discrimination of patients positive or negative for AVN (Table III).

The amount of distraction of hip joint during surgery was significantly lower in patients with AVN than those without AVN $(\mathrm{p}<0.05)$ (Table IV). Cut-off value of amount of distraction was calculated statistically as $4 \mathrm{~mm}$ (area under the curve 0.827 [0.726-0.929]). Sensitivity was $69.2 \%$, positive predictive value was $75.0 \%$, specificity was $85.4 \%$, and negative predictive value was $81.4 \%$ (Figure 4 ).

\section{DISCUSSION}

One of the main and devastating complications associated with the treatment of DDH is the development of AVN. Avascular necrosis of the capital femoral epiphysis leads to femoral head deformity,

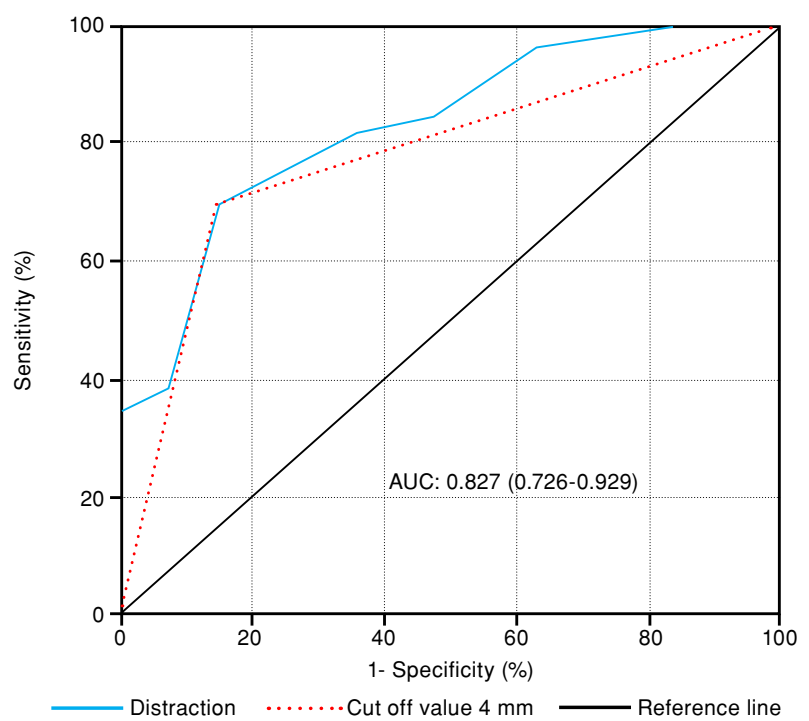

Figure 4. Sensitivity, specificity, and positive and negative predictive value ratios according to cut-off value ( $4 \mathrm{~mm})$. AUC: Area under the curve. acetabular dysplasia, and early onset of osteoarthritis as the child grows and also negatively impacts long-term hip function. ${ }^{[1,2]}$ Avascular necrosis is a catastrophic but preventable complication. ${ }^{[2]}$ However, prevention is only possible if the etiology of AVN is well-known and precautions are taken against the affecting factors.

A great number of studies have researched the factors affecting AVN after DDH treatment and nearly every study has obtained different results with no consensus reached. The main factors researched are patient age at time of reduction, application of preoperative traction, presence of femoral head ossific nucleus, postoperative immobilization technique, anterior or medial surgical approach, and whether pelvic osteotomy and shortening is performed or not. To the best of our knowledge, there is no study on a standardized method to assess the intraoperative tension of surgical reduction. As a result, we planned a study to assess surgical tension objectively and rationally during reduction and also to evaluate factors affecting AVN rates after open reduction including age, gender, pelvic osteotomy and/or shortening, Tönnis degree of dislocation, and intraoperative distraction amounts.

The incidence of AVN in this study was similar to incidences reported in previous studies. ${ }^{[1,15]}$ We did not identify any statistically significant correlation between age and AVN; however, Gardner et al. ${ }^{[16]}$ showed that osteonecrosis rates increased in patients older than 12 months. The association between age at open reduction and AVN remains controversial.

In the literature, there are conflicting results relating to preoperative traction. A study by Thomas et al. ${ }^{[17]}$ showed that preoperative traction has no effect in reducing $A V N$ rates. The publications defending that traction reduces AVN rates are weak in terms of traction type, hip position during traction, duration, and how much weight should be used ${ }^{[18,19]}$ Up to date, the truth is that many centers and surgeons have abandoned preoperative traction. ${ }^{[13]}$ 
After reduction, the immobilization position has been indicated to be important in terms of development of $\mathrm{AVN}$ in the literature. ${ }^{[20]}$ Wide abduction and internal rotation degrees lead to the hip having the risk of AVN development. A study by Smith et al. ${ }^{[21]}$ showed that they immobilized the hips in excessive abduction on computed tomography check-ups after reduction. They found increased AVN rates on followup of these hips. AVN did not develop in any patients with abduction lower than $55^{\circ}$. We immobilized all hips with $30^{\circ}-40^{\circ}$ flexion, $30^{\circ}-40^{\circ}$ abduction, and $10^{\circ}$ internal rotation.

Another method used to reduce AVN rates is femoral shortening. In the current study, we applied femoral shortening to all children older than 24 months. A study by Schoenecker and Strecker ${ }^{[11]}$ comparing cases with traction and femoral shortening showed that femoral shortening was effective in reducing AVN rates. Theoretically, femoral shortening reduces the pressure on the femur head and hence positively reduces AVN rates. In our study, higher AVN rates were found in patients with femoral shortening osteotomy; however, we believe this high AVN rate was due to the older mean age in the group with femoral shortening performed and more advanced Tönnis grade of dislocation. Moreover, Gardner et al. ${ }^{[16]}$ demonstrated that AVN rates increased in children older than 12 months in their systematic review. Galpin et al. ${ }^{[22]}$ and Wenger et al. ${ }^{[23]}$ expanded their indications for shortening to five months. Similar to the literature, in our study, as the preoperative Tönnis dislocation grade increased, AVN rates increased. ${ }^{[24-26]}$

We believe that one of the largest problems and deficiencies today is not assessing the tension of reduction or knowing the pressure acting on the femoral head after reduction. To clearly determine the etiology of AVN, it is necessary to know the pressure on the femur head and we think that setting this pressure to optimal values may reduce $\mathrm{AVN}$ rates to a minimum. To date, there is no objective and standardized technique to assess the tension of reduction. We believe that the pulley system we developed may render this possible. During open reduction, it has been accepted as a rule that the degree of hip decompression is adequate if the surgeon can, with a moderate force, distract the reduced femoral head 3 or $4 \mathrm{~mm}$ from the acetabulum. ${ }^{[13]}$ However, upper extremity strength is mainly dependent on age and gender; also, each human being has different upper extremity strength. ${ }^{[27]}$ Thus, the force generated during traction will be different for different surgeons. Pulling the leg with much strength will lead to more opening between femoral head and acetabulum while pulling the leg with less strength will lead to less opening. This is the most subjective way of evaluating the tension around the hip joint. As far as we know, there is no standardized method of pulling the leg in order to understand the tension around the hip joint. In our current study, multivariate regression analysis found that femoral distraction amount and Tönnis degree were significantly independent factors affecting AVN rates. To the best of our knowledge, there are no studies on this topic in the literature. We believe that our study demonstrates the strongest evidence currently regarding the association between the amount of distraction of the femoral head and AVN.

Our study has several limitations. Many factors are claimed to have an effect on the development of AVN. One of them is the presence of ossific nucleus which we did not examine; however, the mean age of our study population was $21.9 \pm 11.1$ months (range, 9 to 67 months), so nearly all hips in our study had femoral head ossific nucleus. On the other hand, the low number of cases in our study limits interpretation of statistical results. Moreover, the number of assessed hips should have been higher to obtain more powerful statistical results. Another limitation for this study is its retrospective design and short follow-up duration. According to the Salter et al. ${ }^{[28]}$ criteria a minimum of one year is required to diagnose AVN. Unfortunately, the literature does not demonstrate the length of follow-up in which the majority of cases are diagnosed. ${ }^{[29]}$ Follow-up should continue until the patient reaches skeletal maturity since the rate of AVN has been reported to increase with the length of follow-up. ${ }^{[30]}$ Furthermore, retrospective studies risk measurement bias. ${ }^{[14]}$ Another limitation is that although the surgical procedure was the same for all patients, we could not exclude small differences in the procedure between the surgeons. However, both surgeons in the current study had similar levels of experience regarding the surgical treatment of DDH.

In conclusion, we recommend using our technique for the evaluation of the tension of reduction around the hip joint and performing tension free reduction in the treatment of DDH to minimize the risk of AVN development. Every effort should be made to achieve at least $4 \mathrm{~mm}$ distraction, which was calculated as a cut-off value in the current study. We think that femoral shortening osteotomy should be performed in cases with distraction amount less than $4 \mathrm{~mm}$. Moreover, we believe that the reduction tension is the most important prognostic factor in the 
devolopment of AVN. The majority of current studies in the literature are non-randomized level III-IV observational studies; therefore, prospective and randomized controlled studies with high evidence levels are required to better understand the factors affecting AVN rates after surgical treatment of DDH and how to reduce AVN rates.

\section{Declaration of conflicting interests}

The authors declared no conflicts of interest with respect to the authorship and/or publication of this article.

\section{Funding}

The authors received no financial support for the research and/or authorship of this article.

\section{REFERENCES}

1. Malvitz TA, Weinstein SL. Closed reduction for congenital dysplasia of the hip. Functional and radiographic results after an average of thirty years. J Bone Joint Surg [Am] 1994;76:1777-92.

2. Cooperman DR, Wallensten R, Stulberg SD. Post-reduction avascular necrosis in congenital dislocation of the hip. J Bone Joint Surg [Am] 1980;62:247-58.

3. Luhmann SJ, Schoenecker PL, Anderson AM, Bassett GS. The prognostic importance of the ossific nucleus in the treatment of congenital dysplasia of the hip. J Bone Joint Surg [Am] 1998;80:1719-27.

4. Connolly P, Weinstein SL. The course and treatment of avascular necrosis of the femoral head in developmental dysplasia of the hip. [Article in Turkish] Acta Orthop Traumatol Turc 2007;41:54-9.

5. Nakamura J, Kamegaya M, Saisu T, Someya M, Koizumi W, Moriya H. Treatment for developmental dysplasia of the hip using the Pavlik harness: long-term results. J Bone Joint Surg [Br] 2007;89:230-5.

6. Cashman JP, Round J, Taylor G, Clarke NM. The natural history of developmental dysplasia of the hip after early supervised treatment in the Pavlik harness. A prospective, longitudinal follow-up. J Bone Joint Surg [Br] 2002;84:418-25.

7. Gage JR, Winter RB. Avascular necrosis of the capital femoral epiphysis as a complication of closed reduction of congenital dislocation of the hip. A critical review of twenty years' experience at Gillette Children's Hospital. J Bone Joint Surg [Am] 1972;54:373-88.

8. Kahle WK, Anderson MB, Alpert J, Stevens PM, Coleman SS. The value of preliminary traction in the treatment of congenital dislocation of the hip. J Bone Joint Surg [Am] 1990;72:1043-7.

9. Berkeley ME, Dickson JH, Cain TE, Donovan MM. Surgical therapy for congenital dislocation of the hip in patients who are twelve to thirty-six months old. J Bone Joint Surg [Am] 1984;66:412-20.

10. Klisic P, Jankovic L. Combined procedure of open reduction and shortening of the femur in treatment of congenital dislocation of the hips in older children. Clin Orthop Relat Res 1976;119:60-9.

11. Schoenecker PL, Strecker WB. Congenital dislocation of the hip in children. Comparison of the effects of femoral shortening and of skeletal traction in treatment J Bone Joint Surg [Am] 1984;66:21-7.

12. Tönnis D. Nomenclature and classification of congenital hip dislocation. In: Tönnis D. Editor. Congenital Dysplasia and Dislocation of the Hip in Children and Adults. Berlin: Springer-Verlag; 1987. p. 80-3.

13. Herring JA. Devolopmental dysplasia of the hip. In: Herring JA, editor. Tachdjian's Pediatric Orthopaedics. 5th. ed. Philadelphia: Elsevier; 2014. p. 483-535.

14. Aguş H, Omeroğlu H, Uçar H, Biçimoglu A, Türmer Y. Evaluation of the risk factors of avascular necrosis of the femoral head in developmental dysplasia of the hip in infants younger than 18 months of age. J Pediatr Orthop B 2002;11:41-6.

15. Clarke NM, Jowett AJ, Parker L. The surgical treatment of established congenital dislocation of the hip: results of surgery after planned delayed intervention following the appearance of the capital femoral ossific nucleus. J Pediatr Orthop 2005;25:434-9.

16. Gardner RO, Bradley CS, Howard A, Narayanan UG, Wedge JH, Kelley SP. The incidence of avascular necrosis and the radiographic outcome following medial open reduction in children with developmental dysplasia of the hip: a systematic review Bone Joint J 2014;96:279-86.

17. Thomas CL, Gage JR, Ogden JA. Treatment concepts for proximal femoral ischemic necrosis complicating congenital hip disease. J Bone Joint Surg [Am] 1982;64:817-28.

18. Camp J, Herring JA, Dworezynski C. Comparison of inpatient and outpatient traction in developmental dislocation of the hip. J Pediatr Orthop 1994;14:9-12.

19. Daoud A, Saighi-Bououina A. Congenital dislocation of the hip in the older child. The effectiveness of overhead traction. J Bone Joint Surg [Am] 1996;78:30-40.

20. Jaramillo D, Villegas-Medina OL, Doty DK, Dwek JR, Ransil BJ, Mulkern RV, et al. Gadolinium-enhanced MR imaging demonstrates abduction-caused hip ischemia and its reversal in piglets. AJR Am J Roentgenol 1996;166:879-87.

21. Smith BG, Millis MB, Hey LA, Jaramillo D, Kasser JR. Postreduction computed tomography in developmental dislocation of the hip: part II: predictive value for outcome. J Pediatr Orthop 1997;17:631-6.

22. Galpin RD, Roach JW, Wenger DR, Herring JA, Birch JG. One-stage treatment of congenital dislocation of the hip in older children, including femoral shortening. J Bone Joint Surg [Am] 1989;71:734-41.

23. Wenger DR, Lee CS, Kolman B. Derotational femoral shortening for developmental dislocation of the hip: special indications and results in the child younger than 2 years. J Pediatr Orthop 1995;15:768-79.

24. Binnet MS, Chakirgil GS, Adiyaman S, Ates Y. The relationship between the treatment of congenital dislocation of the hip and avascular necrosis. Orthopedics 1992;15:73-81.

25. Rosen A, Gamble JG, Vallier H, Bloch D, Smith L, Rinsky LA. Analysis of radiographic measurements as prognostic indicators of treatment success in patients with developmental dysplasia of the hip. J Pediatr Orthop B 1999;8:118-21.

26. Yorgancigil H, Aslan A. Comparison of the clinical and radiological outcomes of open reduction via medial and anterior approach in devleopmental dysplasia of the hip. Eklem Hastalik Cerrahisi 2016;27:74-80. 
27. Metter EJ, Conwit R, Tobin J, Fozard JL. Age-associated loss of power and strength in the upper extremities in women and men. J Gerontol A Biol Sci Med Sci 1997;52:267-76.

28. Salter RB, Kostuik J, Dallas S. Avascular necrosis of the femoral head as a complication of treatment for congenital dislocation of the hip in young children: a clinical and experimental investigation. Can J Surg 1969;12:44-61.
29. Luedtke LM, Flynn JM, Pill SG. Review of avascular necrosis in developmental dysplasia of the hip and contemporary efforts at prevention. The University of Pennsylvania Orthopaedic Journal 2000;13:22-8.

30. Akilapa O. The medial approach open reduction for developmental dysplasia of the hip: do the long-term outcomes validate this approach? A systematic review of the literature. J Child Orthop 2014;8:387-97. 